\title{
Manifestation of Multilingualism in School Ideology, Environment and Practice: An Ethnographic Survey of Case Examples from Schools in Europe
}

\author{
Ülle Säälik \\ Narva College, Estonian Military Academy, \\ University of Tartu, Estonia \\ ulle.saalik@ut.ee
}

\begin{abstract}
The changing world with spreading immigration, expanding linguistic and cultural variety, and growing demand for implementing inclusion in education has created a difficult situation, challenging for teachers, educators, and policy makers. The aim of education is no longer academic achievement, but educational laws state the need for preparing pupils for life in linguistically and culturally diverse societies, demanding systematic analyses and creative approaches (e.g. Anderson 2011; Piccardo 2017). Promoting one's ability to cope with and within different language environments is believed to give the person several advantages, such as being more successful, easily adapting to changes and fully participating in societies (e.g. Cenoz 2009; Housen 2002). Schools promoting the use of two or more languages, aiming at multilingualism and multiliteracy in one way or another, were the target of the current ethnographic research in which the real-life observations and free form interviews in several schools in Europe were made.
\end{abstract}

Keywords: multilingualism, school, educational policy

Some countries have long traditions and well-working systems for dealing with people from different backgrounds and with different languages, while others struggle hard to implement necessary changes to welcome refugees and newcomers or simply cope with the diversity of the local community. How to offer the normative level of education to those with a home language different than the instructional language at schools, minorities in the area or even marginalized population groups, if the educators do not know how to manage it? The basis for the current research is that everyone deserves the possibility of receiving appropriate education, and therefore their different home language must not be seen as a problem to be eliminated, but rather as a variety to be recognized.

Several authors have argued about the issue of multiple languages in the 
educational context, proposing typologies, theoretical models, principles, and effect factors (e.g. Baker 1996; Cenoz 2009; García 2009; Mehisto and Genesee 2015, etc.). The research papers on the topic mostly focus on classroom practices, or student, teacher or school characteristics, but the overall context, ideology or community attitudes and expectations behind it all are often left unconsidered. Yet, the way people think about the issues in education affects the ways these issues are handled. As for the issue of several languages in education, Auer and Wei $(2009,3)$ stated one of the most fundamental questions as follows: Do we see monolingualism as a norm, and multilingualism as a problem that needs to be 'cured' or the other way around? The variety of approaches, policy statements, educational practices, and the rationale behind these decisions can be confusingly varied, indeed. It is not always clear to the participants in education why the things are approached one way or another, but sometimes these approaches may be perceived as unfair, unjust or unreasonable. This is the reason why policy, ideology and attitudes should be carefully reflected on before applying different educational practices, and this frame of mind should be clearly and consistently communicated to all the participants.

The present paper proposes a short ethnographic overview of several different cases from all over Europe, with different school ideologies and practices for dealing with students with different home languages, with the aim of presenting the variety of approaches and customary social behaviours, reasoning for the choices, the views of social life, etc., collected while participating and communicating with the members of the studied groups, which is the essence of ethnographic studies (Estenberg 2002, 58-59). Results of participating observations, document analyses and participant interviews are presented, and examples of educational practices alongside the ideology and attitudes behind them are discussed. Six cases of schools from Germany, Italy, Latvia, Finland, and Estonia are presented in the current paper, yet they are not the representatives of those countries, but must be perceived rather as autonomous examples which give us certain framing for different possibilities of how to approach the issue of multiple languages in education. The results were linked with the known ideologies, programme types, and pedagogical practices based on García (2009), and Reljić, Ferring and Martin (2015) (see figure 1).

The issue of language may be seen as an obligation or a right, a problem, an opportunity or as a resource. The issue of languages in education is believed to be intertwined with ideological aspects so that no-one is entirely free of biases, which might have influence on research, as well as political deci- 


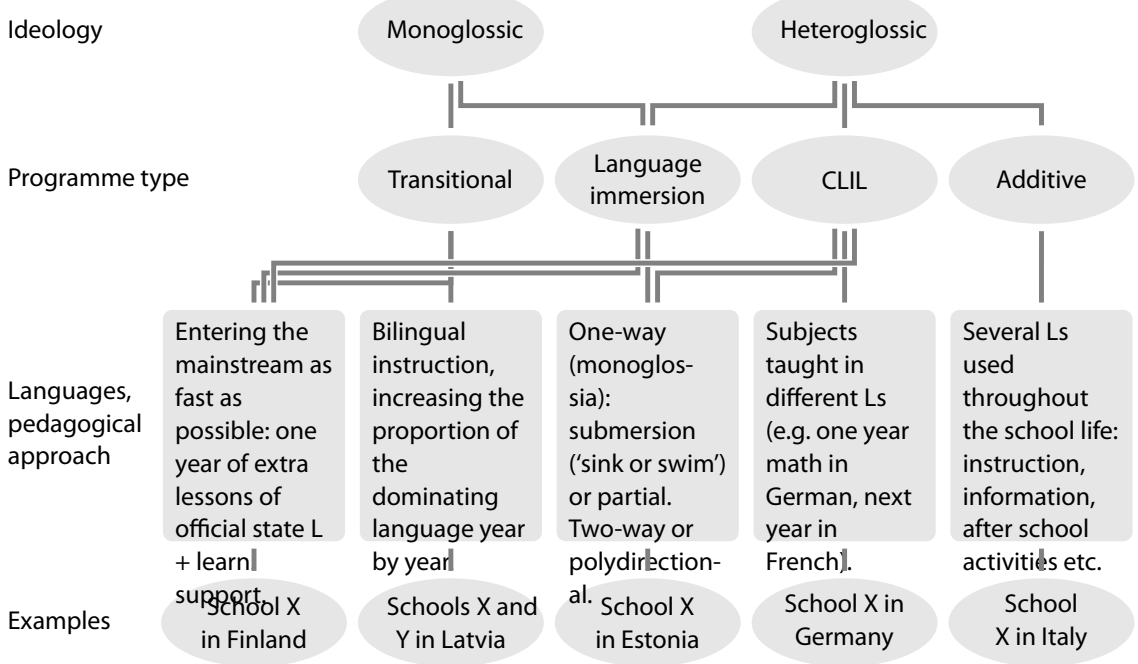

Figure 1 Examples of Schools' Approaches Linked with the Ideologies, Programme Types, and Pedagogical Practices (author's inference of results based on theory by García (2009), and Reljić, Ferring, and Martin (2015))

sions (Rossell and Baker 1996, cited in Rolstad, Mahoney, and Glass 2005, 573). Ideologies may be based on the ambition to obtain the standards of the dominating language and for other languages to be strictly considered as foreign languages, taught in separate classrooms as separate subjects, often referred to as a weak or subtractive language programme, transitioning or submerging learners into school and society with its dominating language environment. The result of such an approach is the ability to use the dominating language plus one or two separate foreign languages, which ends up as parallel monolingualism or monoglossia. A more liberal approach emphasizing principles of social justice, also referred to as a strong or additive programme, considers languages as an added value and the knowledge of other languages as additive, aiming at the entwined ability to use several languages smoothly as bilingualism, plurilingualism, heteroglossia (e.g. Busch 2015; García 2009; Reljić, Ferring, and, Martin 2015; Weber 2014).

\section{School X in Finland: Decades of Experience with Teaching Immigrant Children}

\section{Background}

De jure a bilingual country with two official languages, Finnish and Swedish, de facto a multilingual and multicultural country with a growing diversity 
of population. The numbers of people with an immigrant background have rapidly increased, for example in 2005 there were about 150 thousand; in 2017 it was already 360 thousand people. 'The government has initiated a national programme called Vastaantulo (Meeting in the Middle) to help them fit into the educational system as well as in society, and to study and develop the process of school integration of newcomers' children. ${ }^{2}$ The first year after entering the school system is called the year of the Finnish language when children mostly learn the language and get accustomed to school. There are several support systems to help newcomers cope with learning in the classrooms with Finnish as an instructional language. The local municipality is obliged to offer some learning of each one's mother tongue, should the family wish for it, yet, the opportunity is not used very often, as the schooling may not be available at that particular school, but one may have to travel to another school a few times a week, and that is found to be too inconvenient.

The observed primary school had almost one third of pupils with an immigrant background, varying highly according to their linguistic, socioeconomic and cultural background.

\section{Inputs: Policy, Resources, Curriculum}

The school policy was driven by the regional mission and the need to take multilingualism and multiculturalism into consideration. The proportion of the population with a migrant background in the area was rather high with a rather low socioeconomic status. The school staff and management shared a common accepting and tolerant attitude. They had had a long time experience with teaching children from other countries and with other home language, they had come up with solutions to it, and thus dealing with immigrant children was perceived as a normal part of their job.

The school was well equipped with necessary technical devices such as document projectors, adjustable tables and chairs as well as printer-scanners to create one's own handouts with coloured printing, etc. There were extra resources available from the municipality should the family need some extra support, learning aid, etc. Fourteen teachers had had preparation for dealing with children with special educational needs. Most groups were taught with two teachers present, and some students had assistants to support their learning and coping in the school environment.

The regular teacher training does not include preparation for teaching learners with a home language other than the school instructional language

\footnotetext{
${ }^{1}$ See http://www.stat.fi/tup/maahanmuutto/maahanmuuttajat-vaestossa_en.html.

${ }^{2}$ See https://blogs.helsinki.fi/vastaantulo/in-english/.
} 
but teaching in a multicultural context as well as the principles of inclusive education are present in the teacher training curricula. In-service training about content and language integrated learning (CLIL) is also available.

There was a lack of learning materials available for special needs, especially for linguistic needs of children with a different home language. The teachers said they often prepare their own materials and share them in unofficial teacher support groups.

After the first year, the stem of the curriculum was the same for everyone with slight differences for learners with Finnish as the mother tongue ( $\mathrm{S}_{1}$ ) or as a foreign language ( $\left.\mathrm{S}_{2}\right)$. There was one instructional language (Finnish), and other languages were learnt as separate foreign language subjects. Language immersion practice was used during the first years, and CLIL methodology throughout the primary level. By the end of compulsory primary education, language proficiency ought to be equal. The ideology towards languages appeared to be transitional with the goal for students to enter mainstream education as quickly as possible, and for every citizen to obtain one of the official national languages (Finnish) to converge into society.

\section{Processes: Climate, Attitudes, Practices and Cooperation}

The overall social and emotional atmosphere in the school felt calm and friendly, no segregation was detected. Children were playing outdoors during the breaks and sitting around the schoolhouse with no visible grouping according to skin colour or other cultural characteristics. The school environment appeared to be culturally sensitive and welcoming of differences as there are several posters, drawings or signs in different languages and objects that present different cultures, such as flags or other symbols (figure 2).

The school staff expressed support for inclusion and an individual approach in education. They said that there was no need or no time to differentiate their teaching specially towards different languages or cultures, but multilingualism and multiculturalism as such were appreciated and valued. 'They are all the same. They are all our pupils,' they said. Collaboration between staff members appeared to be the shared key value. While younger learners seemed very proud to point out the languages they speak and countries they come from, in older groups the pupils acted upset when the teacher asked about their origin. They seemed to be reluctant to reply about their origin or home language, continuing speaking in Finnish.

The teaching approach on the primary level appeared inclusive and tolerant in many ways, considering individual needs as a very natural way of teaching in compulsory education. The language of instruction is Finnish, yet the preparatory year included some English. Learning skills were also devel- 
Figure 2

The Poster on the Classroom Door Welcomes Everyone in a Large Variety of Languages That Are Spoken by Children Studying in That Class

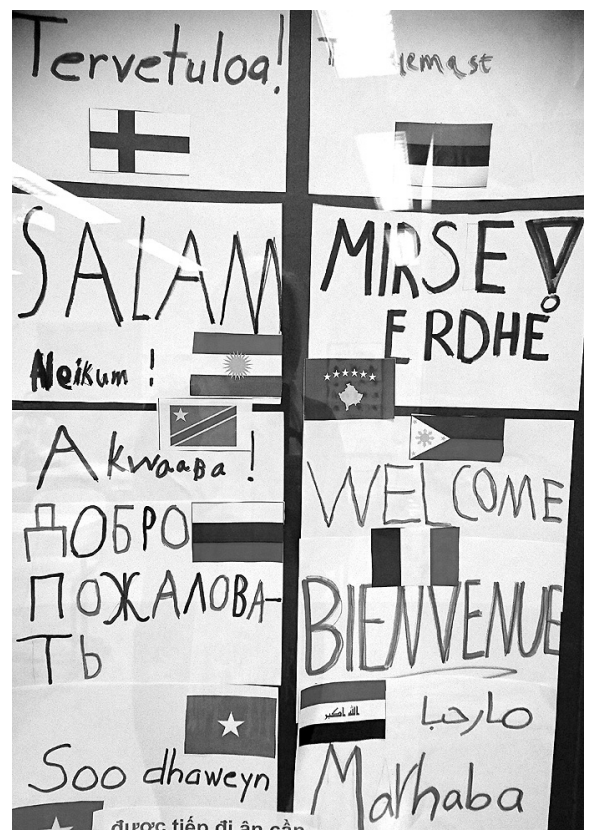

oped during teaching as well as norms of behaviour in the academic context such as raising one's hand when being ready to give a reply to the teacher's questions. The learning routine seemed to be mostly well taken up and that seemed to make the pupils feel comfortable and confident in this learning situation.

The elements of self-directed learning and collaborative learning were noticed. Dialogical teaching, student-centeredness and student involvement in learning dominated in all observed lessons. Active and helpful children also offered some peer-support while learning. The teacher helped by using prompts, hand gestures, facial impressions and mimicking, but then gave children the initiative. The child could decide whether he or she wanted someone to help him or her as well as let other children give feedback to the given answers and did not only approve the replies by her/himself as the authority.

\section{Schools $\mathrm{X}$ and $\mathrm{Y}$ in Latvia: Bilingual Teaching and Increase} of Latvian Step-by-Step

\section{Background}

De jure the official language is Latvian, de facto about half of the population are non-Latvians, e.g. in this capital area the population consists of $47 \%$ Lat- 
Table 1 An Example of a School Curriculum and the Change in the Proportion of the Languages of Instruction during the Period of Nine Years

\begin{tabular}{lrrrr}
\hline Year & Latvian & Foreign & Russian & Bilingual \\
\hline Year 9 & 64.71 & 11.76 & 23.53 & 0.00 \\
Year 8 & 61.76 & 11.76 & 26.48 & 0.00 \\
Year 7 & 53.13 & 12.50 & 15.62 & 18.75 \\
Year 6 & 50.00 & 13.33 & 16.67 & 20.00 \\
Year 5 & 46.43 & 14.28 & 39.29 & 0.00 \\
Year 4 & 42.31 & 15.38 & 34.62 & 7.69 \\
Year 3 & 37.50 & 12.50 & 41.67 & 8.33 \\
Year 2 & 34.78 & 4.35 & 47.83 & 13.04 \\
Year 1 & 27.27 & 4.55 & 50.00 & 18.18 \\
\hline
\end{tabular}

vians, $37 \%$ Russians, and $16 \%$ others. The compulsory official language used in national and municipal institutions is also Latvian. ${ }^{3}$ The language of instruction in higher education institutions as well as in vocational schools is Latvian. Schools with Russian as the language of instruction are called minority schools. In schools $X$ and $Y$ the pupils' home language was Russian.

\section{Inputs: Policy, Resources, Curriculum}

The schools' policy was driven by the current national reforms. As the pupils' home language is different from the national language of the country, the school needed to implement a step-by-step transition to only Latvian as the language of instruction (table 1), which was boosted by the pressure of national exams previously being held in either Russian or Latvian, then in Latvian with the possibility to answer in Russian and finally demanding responses only in Latvian. As schools are regularly rated in the country according to exam results and other outcomes by the Ministry of Education, and school $X$ had just been through the accreditation and external evaluation processes, that had put extra pressure on the school to follow the policy demands of national educational reforms. The school had already introduced having several subjects taught in two languages (referred to as bilingual classrooms) and that needed some further adjustments such as implementing bilingual lessons regularly and systematically throughout all school years, as shown in table 1.

Teachers must have $C_{2}$ level of Latvian, which is carefully checked by the government, and due to that schools tend to report not having enough qual-

\footnotetext{
${ }^{3}$ See http://www.izm.gov.lv/en/education/education-system-in-latvia.
} 
Figure 3

Latvian National Symbols Displayed Everywhere in the School Environment Due to the Recent 10oth Anniversary of the Independence of the Latvian Republic

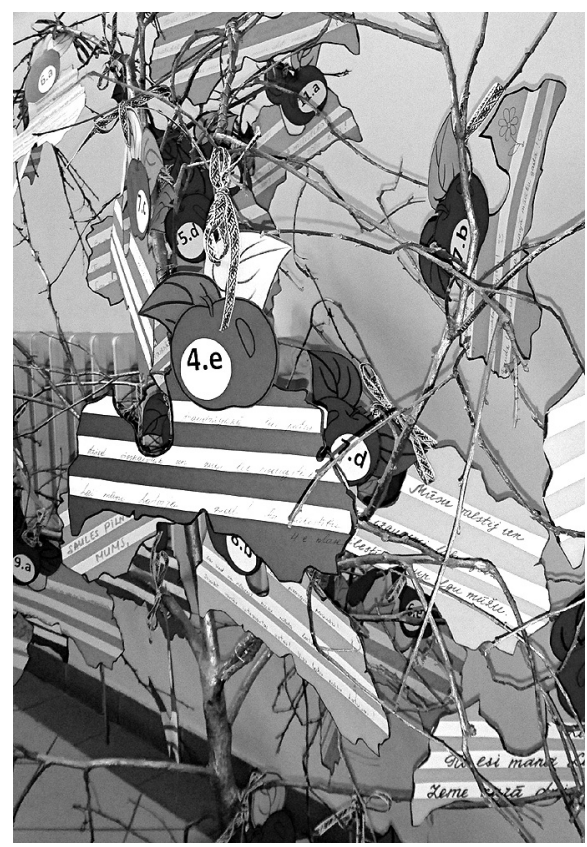

ified teachers. It was possible for schools to get extra funding for teaching Latvian, but as the head of the school said, 'What can you do with the money, when there is no-one to send to the classrooms as most teachers work with heavy overload already now?' There was also a lack of learning resources, especially for bilingual classrooms. This issue was solved by the heads of schools and teachers by preparing and publishing their own bilingual books. There were support specialists available such as speech therapists, psychologists or specialists in social pedagogy.

\section{Processes: Climate, Attitudes, Practices}

National symbols of Latvia were manifested everywhere in the schoolhouses (figure 3). Achievement, progress, and contemporariness seemed to be highly valued in the schools. Displays with honor certificates and trophies as well as recognitions of international projects conducted were displayed in the most visible places (figure 4).

Most official signs were either in Latvian or in Latvian and English, while non-official notices such as behavioural instructions or attention signs were in Russian (figure 5). The instruction in the classrooms was given mostly in Latvian with occasional explanations in Russian. 


\section{Figure 4}

Displays with Honor Certificates, Trophies and Recognitions of International Projects Conducted Put on Display in the Most Visible Places

\section{Figure 5}

Informal Notifications Often Displayed in Russian

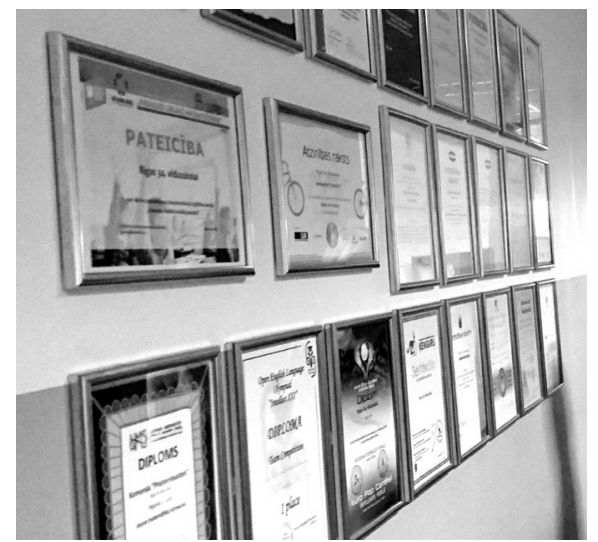

Ты ведь соблюдаешь

правила? Не надо

бегать по коридорам!!

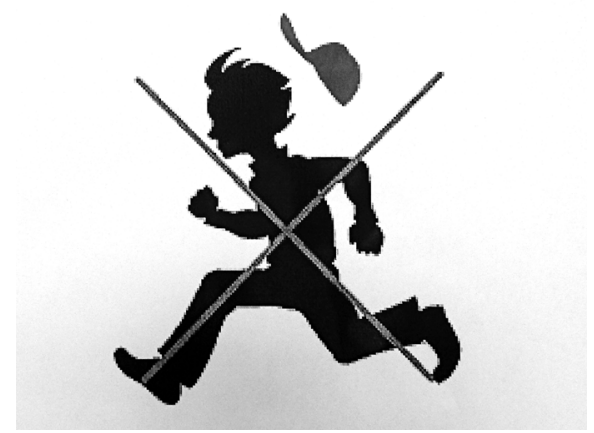

Informing and persuading parents was considered highly important before the changes that took place a few years ago. The school staff felt some agitation from parents, but after some persuasion of how useful the new system would be for their children, and how smoothly and safely the transition would take place, the situation cooled down.

The attitude towards the increasing proportion of Latvian was ambivalent: somehow it seemed to have caused problems and irritation, but the understanding of its uses and usefulness was present. There were still some movements in the society accusing the government of discrimination of the human rights of the Russian-speaking population due to this transition to the 
Figure 6

Example of a Bilingual Textbook
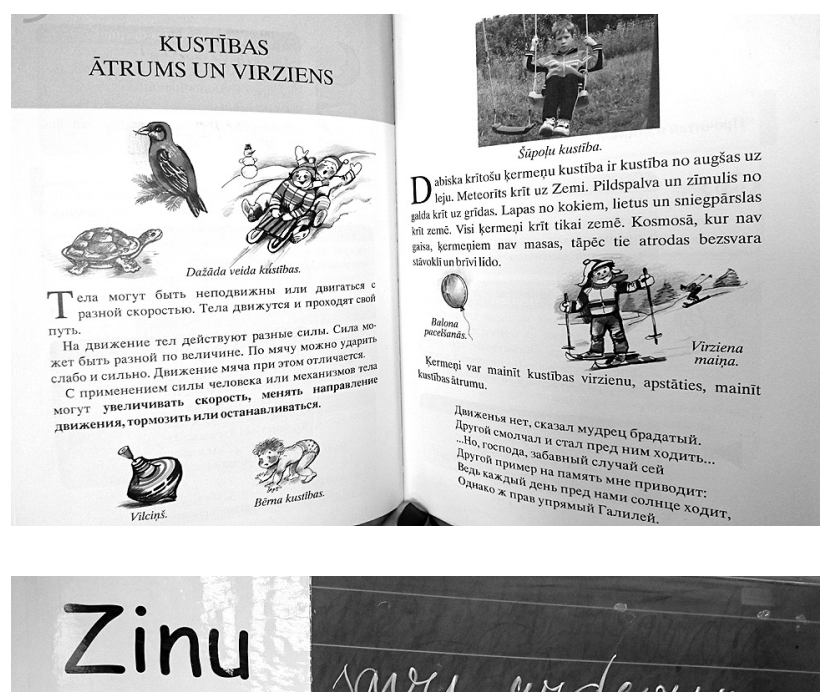

saver azdeoumu

Figure 7

Learning Outcomes of 'Know, Understand, Can Do' Permanently Displayed on the Class Board for a Teacher to Add Expected Outcomes of the Current Learning Activity

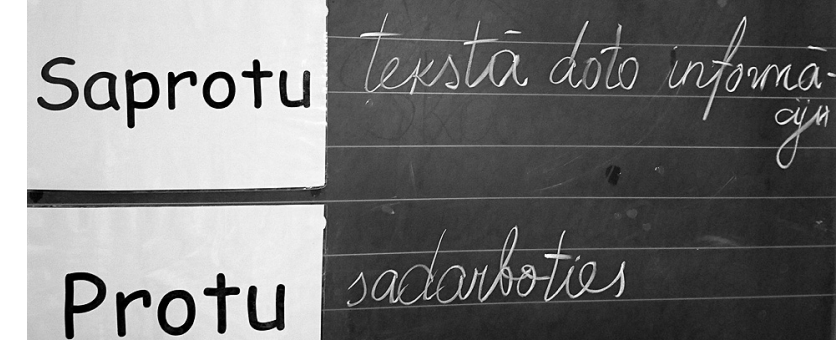

Latvian language. Yet, people felt the tension had relieved after people realized it would give children a better head start and opportunities in life. The schools also contributed to improvement of bilingual learning by creating and publishing their own textbooks, in which some tasks were in Latvian and others in Russian or some more difficult parts were explained in Russian while accompanying a task in Latvian (figure 6).

The use of contemporary educational practices was detectable in classrooms. On the classroom boards there were permanent signs referring to learning outputs which the teacher would point out or write at the beginning of the lesson, and at the end of the lesson the teacher would ask children to assess if they achieved those goals, although they were not always used (figure 7). Student-centred methods were used, but the teachers still appeared to be strictly leading the process, acting as disciplinarians and pushing children to keep a fast pace in learning. 


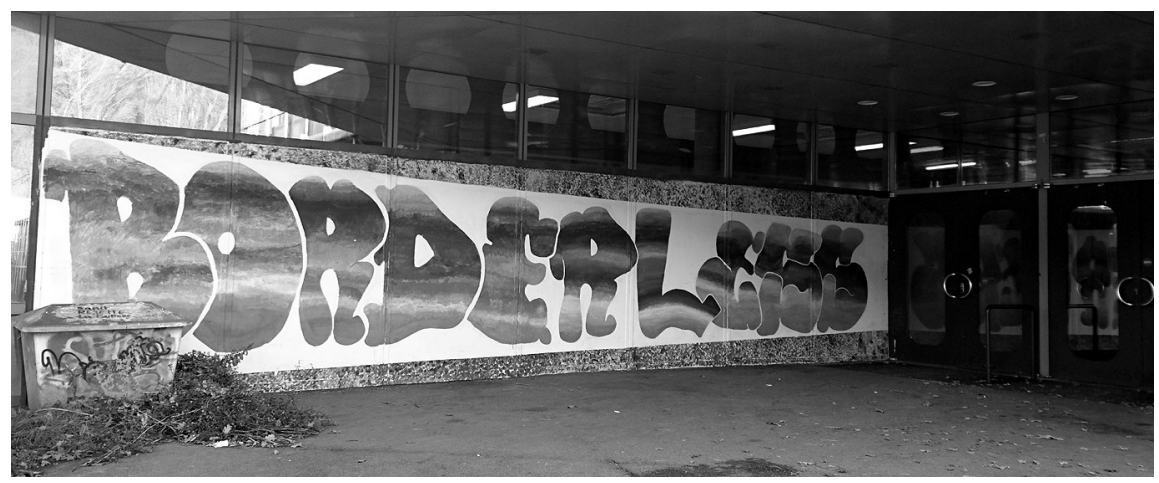

Figure 8 A Symbolic Message at the Main Entrance Promoting the 'Borderless'-Mind-Set

\section{School X in Germany near the Border of France: Dynamic Bilingual Curriculum as a Natural Way to Learn \\ Background}

The school is located in Germany, but very close to France. The population can also be described as diverse, mostly German and French speakers, but also with a high rate of immigrants and refugees. The need for better linguistic skills has been accepted for decades already both by parents and school.

\section{Inputs: Policy, Resources, Curriculum}

The school policy was driven by the local demographic situation and the need to develop the competence of both languages. It had officially been bilingual for decades after the treaty between the two countries, also funded by the two countries. Families could choose the intensity or direction of the curriculum as well as the choice of languages in which learning will take place. For example, maths could be studied as a regular or intense course in German for some years and then in French for some years, etc. The principle of choosing teachers was that he or she should be a native speaker of that instructional language to avoid the negative effect of learners being exposed to poor language.

\section{Processes: Climate, Attitudes, Practices}

The school was very popular among parents on both sides of the country border. Bilingual teaching aiming at competence in both target languages was considered a great advantage for children. Therefore, the attitudes of learners all over the school towards learning could be described as positive, involved and enthusiastic. Shifting between the languages among both chil- 
Figure 9

An Example of a Hands-on Learning Method in a Music Lesson, Where Colourful M\&Ms Sweets Were Used as Notes to Set on Staves and Then Play the Melody, Sharing the Result with a Peer

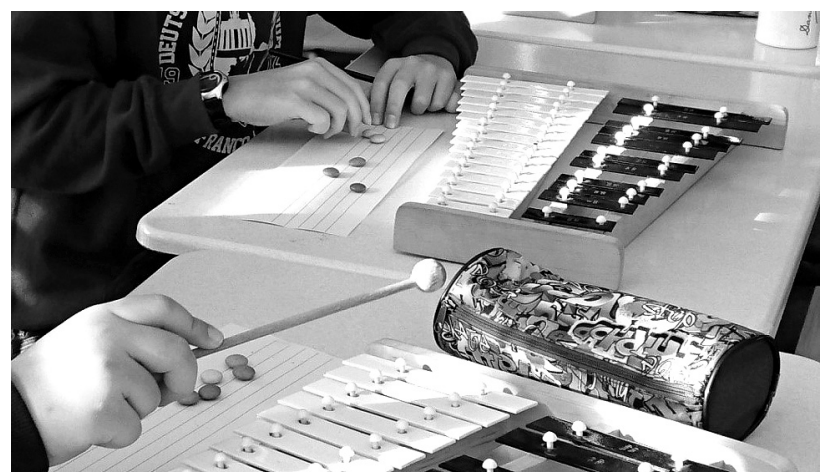

dren and staff was natural and smooth during the lessons as well as breaks. A teacher would give instructions in French, then approach a child in German, then repeat in French again, checking for understanding and continuing in French. One can also find manifestations of tolerance, for example the rainbow-coloured sign stating 'borderless' near the front door (figure 8).

The educational practices in the classrooms had good dynamics with enthusiastic warm-ups, short, clear explanations and demonstration followed by playful practice. For example, the rhythms of tunes were set on music staves using M\&Ms colourful sweets, and then a pupil tried to play the tune set by his/her friend (figure 9).

\section{School X in Italy: Hobby Classes Conducted in Several Languages as} Part of Curriculum and Everyday Practice, Arts, Music and Dance Seen as a Universally Understood Language

\section{Background}

De jure a trilingual area (Italian, German and Ladin), de facto multilingual and multicultural with a growing number of migrants and refugees. The area, although trilingual for a long time, has rather strong segregation in the community. There may be Italian shops and German shops with customers mostly of the same home language. There is also a demand at the university to provide courses in all those languages, but certainly in separate groups.

\section{Inputs: Policy, Resources, Curriculum}

School policy was driven by the need to offer good education both to local children and to those with a migrant background as well as with a refugee background and minor experience of schooling, if hardly any at all. School life was based on the belief that every child can do something very well, and that 
arts, music, dance, etc. were a universal language understood by everyone, offering everyone a chance to feel competent, included, and accepted even if failing in the main instructional language(s) of the school. It was considered highly important to build a positive attitude towards school and learning in general and to decrease anxiety and discomfort, which often occurred in the case of children arriving from countries in crisis or in war.

\section{Processes: Climate, Attitudes, Practices}

It should be noted that it is not very common for a school in Italy to make its own decisions about its policy and practices. The educators expressed their worries about the governmental policy being too rigid and not giving the school enough autonomy in such decisions. The head of that school was convinced that their approach was the best for their situation and kept proving it to the authorities as well. Yet, the tension between governmental demands and the school's choices was not at all perceived in the school environment. The overall atmosphere was rather joyful, free and full of positive energy which reflected from the energetic actions in the classrooms, both teachers' and children's faces or from the nature of children's art work displays that were presented all over the school.

After-school activities were a regular part of the curriculum in this school. It means that besides regular school subjects the children attend hobbyclasses. These hobby-classes take place several times a week, and the instruction might be given in a variety of languages, sometimes in Italian, sometimes in English or German or in the language which the teacher speaks. It was believed that one can follow dance movements or sing along even if not understanding every word the teacher says, and that language awareness would increase in such an immersive environment, first getting used to the language and then starting using it.

At the beginning of the school year children could try out several options, and then they would choose one they would like to go on with during the rest of the school year. The autonomy given to children by that choice of hobbyclasses was probably one of the reasons why children seemed so devoted and diligent while practicing playing musical instruments or circus acts.

\section{School X in Estonia: Examples of Implementing Immersion and CLIL in the Context of Monoglossic Educational Ideology}

\section{Background, Inputs: Policy, Resources, Curriculum}

School $\mathrm{X}$ is located in Estonia in the area with a population speaking mostly Russian, yet the education policy and regulations demand at least $60 \%$ of 
Figure 10

Not Only Talking Walls, But Also Talking Stair Steps in the Schoolhouse

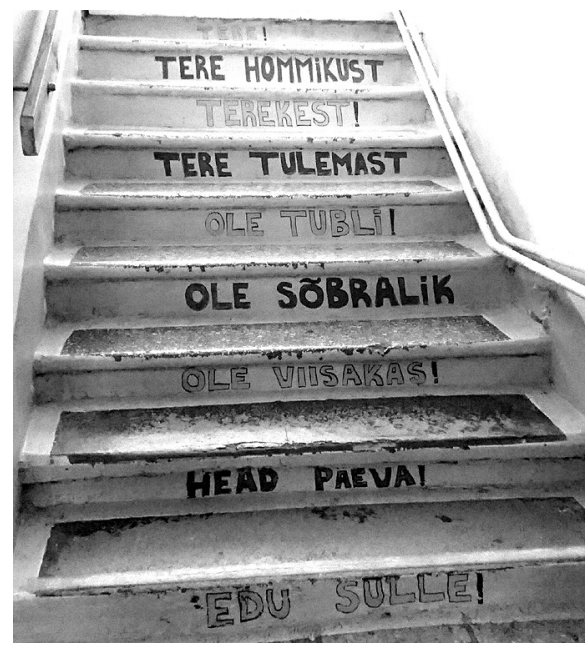

Estonian as the language of instruction in upper-secondary schools, which puts some pressure on the school in finding ways of getting their students to that level of being able to use Estonian. It is rather popular in the area to have language immersion applied at the lower primary level of education.

\section{Processes: Climate, Attitudes, Practices}

Everywhere in the school one could notice a variety of visual representations of the language which is seen as the target language. There were not only talking walls, but also talking stair steps (figure 10), which were expected to support language acquisition. The elements of educational tools used in language immersion appear in most primary classrooms (e.g. pictograms, object labels etc.), yet there were less and less supporting elements in rooms for older students.

The school environment itself was a mixture of old soviet-time relicts such as cloakrooms with metal bars or rigid two-place desks in rows alongside some contemporary technology elements such as digital screens or vending machines (figure 11). In school halls the staff had put some effort into creating some elements that stimulate students to move around, such as hopscotch or balance trails, which is a growing trend in Estonian schools. Yet here, the painted figures seem to be fading already, which means this school has been working on trendy elements for quite some time already. Also, in the classrooms one could observe elements of contemporary learning approaches such as learning aims on the board (I know, I understand, I can do) or talking walls everywhere. The teachers applied a variety of lan- 
Figure 11

Modern and

Bygone-Times Elements

in the School

Environment: Digital

Information Screen,

Digital Welcome

Display Using Three

Different Languages, a

Beverage Vending

Machine Alongside a

Cage-Like Barred and

Locked Cloakroom

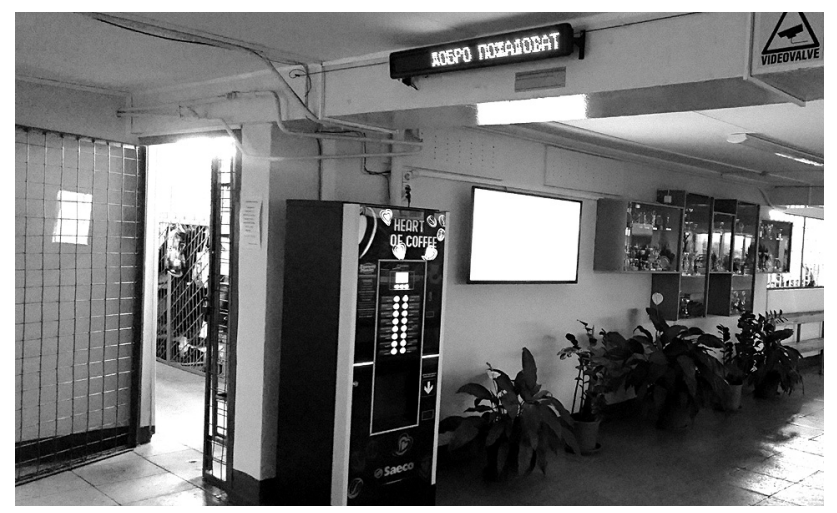

guage immersion methods in primary classrooms, but also exploited intensive textbook-workbook practice with the 'teacher asks-student answers'manner to achieve better results, as they said. In secondary classrooms more of a teacher-centred approach was observed.

\section{Discussion}

When going to visit a school in another country it is highly relevant to keep in mind that before comparing of the seen with what we know about education and before making any judgements, one should be aware of the educational setting made up of the educational policy, traditions, cultural or demographic aspects, etc. Seeing inspiring methods or fascinating approaches somewhere abroad becomes developmentally useful if one considers the context, regulations and people's mindsets about the arguments for such solutions. Another important aspect is to spend some time in those schools, truly be there as part of their everyday life and see, hear and perceive what lies behind their understanding.

The allocation of the school's ideology and practice into certain specified categories, as shown in figure 2, was created by the author after careful consideration of the essence of categories with strong emphasis on the objectives of education in those schools and its comparison with what was perceived while participating, observing, and questioning. The fear of being judged poorly or accused of being not very contemporary and not very effective was felt more in the post-soviet countries and much less in conventional European countries. In Estonia and Latvia school heads tended to give more evidence of their good results and reputation, sometimes tending to apologize for not being able to implement all useful ideas or innovative equipment so far, and teachers appeared keener on showing all their repertoire of 
methods in one lesson, while children did not always recognize the practice, referring to the method not being applied often enough to be recognized by children.

As an educator, adapting a single method or an approach in one's classroom or schools may seem a feasible task, while introducing the whole programme or ideology may be perceived as too complicated and hard to do, therefore the approach may die out after the enthusiast of the school leaves. Although the methods of language immersion have been accepted in very many educational institutions in Estonia, the wider and more tolerant ideology of heteroglossia is not easily accepted. Despite having the competence of three languages present in the Italian area, instead of making use of such an advantage for true development of multilingualism in education and promotion of heteroglossia, the schools and universities mostly separate their students by their language.

It can be concluded that the broader awareness of diversity of languages as well as the tolerance towards such diversity still need to be disseminated. To achieve the coherence between educational policy, school policy and practice and people's mind-set and actions in our schools as well as community, some more research in this field needs to be conducted with a wider approach involving all the different levels of education and considering the context as well.

\section{Acknowledgements}

The school visits took place as part of the Erasmus+ Project funded by the European Union and the Estonian Research Council's programme RITA supported by the European Regional Development Fund.

\section{References}

Anderson, Jim. 2011. 'Reshaping Pedagogies for a Plurilingual Agenda.' Language Learning Journal 39 (2): 135-47.

Auer, Peter, and Li Wei. 2009. 'Introduction: Multilingualism as a problem? Monolingualism as a problem?' In Handbook of Multilingualism and Multilingual Communication, edited by Peter Auer and Li Wei, 1-14. Berlin: Mounton the Gruyter.

Baker, Colin. 1996. Foundations of Bilingual Education and Bilingualism. 2nd ed. Clevedon: Multilingual Matters.

Busch, Barbara. 2015. 'Linguistic repertoire and Spracherleben, the Lived Experience of Language.' Working papers in Urban Language \& Literacies 148, King's College London, Centre for Language Discourse \& Communication, London. 
Cenoz, Jasone. 2009. Towards Multilingual Education: Basque Educational Research from an International Perspective. Bristol and Buffalo: Multilingual Matters.

Estenberg, Kristin G. 2002. Qualitative Methods in Social Research. Boston, MA: McGraw-Hill Higher Education.

García, Ofelia. 2009. Bilingual Education in the 21st Century: A Global Perspective. Chichester: Wiley-Blackwell.

Housen, Alex. 2002. Processes and Outcomes in the European Schools Model of Multilingual Education. Bilingual Research Journal 26 (1): 43-62.

Mehisto, Peeter, and Fred Genesee, eds. 2015. Building Bilingual Education Systems: Forces, Mechanism Sand Counterweights. Cambridge: Cambridge University Press.

Piccardo, Enrica. 2017. 'Plurilingualism as a Catalyst for Creativity in Superdiverse Societies: A Systemic Analysis.' Frontiers in Psychology 8 (2169): 1-13.

Reljić, Gabrijela, Dieter Ferring, and Romain Martin. 2015. 'A Meta-Analysis on the Effectiveness of Bilingual Programs in Europe.' Review of Educational Research 85 (1): 92-128.

Rolstad, Kellie, Kate Mahoney, and Gene V. Glass. 2005. 'The big Picture: A MetaAnalysis of Program Effectiveness Research on English Language Learners.' Educational Policy 19:572-94.

Rossell, Christine H., and Keith Baker. 1996. 'The Educational Effectiveness of Bilingual Education.' Research in the Teaching of English 30 (1): 7-74.

Weber, Jean Jacques. 2014. Flexible Multilingual Education: Putting Children's Needs First. Bristol: Multilingual Matters. 